\title{
Effects of phytoplankton taste and smell on feeding behavior of the copepod Centropages hamatus*
}

\author{
Kathryn L. Van Alstyne** \\ Woods Hole Oceanographic Institution, Woods Hole, Massachusetts 02543, USA
}

\begin{abstract}
Adult copepods Centropages hamatus were induced to feed on 10 to $40 \mu \mathrm{m}$ Sephadex beads by adding Thalassiosira weissflogii or Scrippsiella trochoidea wholecell extract, or filtrate from a $T$. weissflogii culture, to a bead suspension. Beads were neither ingested in the absence of a chemical stimulus, nor in the presence of filtrates from cultures of $S$. trochoidea and Olisthodiscus luteus, or O. luteus extracts. Extracts from both $S$. trochoidea and $O$. luteus, and filtrate from an $O$. luteus culture, appear to exert an inhibitory effect when applied in combination with $T$. weissflogii extract. Copepods acclimated to $T$. weissflogii for $24 \mathrm{~h}$ did not significantly increase their feeding rate on $T$. weissflogiiflavored beads and did not ingest $S$. trochoidea-flavored beads.
\end{abstract}

Food choice by herbivorous copepods can be influenced by the size, shape and chemical composition of potential prey. Earlier studies of food choice by copepods focused on the effects of phytoplankton size because copepods were thought to be passive filter feeders and limited in their ability to actively select food items (e.g. Boyd 1976, Nival \& Nival 1976, Frost 1977). However, since Alcarez et al. (1980) and Koehl \& Strickler (1981) have shown that copepods actively select their prey, more studies have focused on the role of chemical stimuli produced by the prey in determining food choice by copepods (e.g. Donaghay \& Small 1979, Huntley et al. 1983). Huntley et al. (1986) have shown that Calanus pacificus and Paracalanus parvus reject particular dinoflagellate species and that in one case the rejection is based upon the presence of exudates released by the alga.

Here, I show that feeding behavior in the herbivorous copepod Centropages hamatus can be stimulated by Thalassiosira weissflogii whole cell homogenates or

\footnotetext{
- Research supported by Summer Student Fellowship from Woods Hole Oceanographic Institution and by National Science Foundation grant OCE 82-15188 to Timothy J. Cowles -. Present address: Department of Zoology NJ-15, University of Washington, Seattle, Washington 98195, USA
}

by filtrates taken from cultures of these cells. I further document that the presence of homogenates or filtrates of 2 other phytoplankton species, Scrippsiella trochoidea and Olisthodiscus luteus, can inhibit feeding in these copepods.

Material and Methods. Thalassiosira weissflogii (Bacillariophyceae), Scrippsiella trochoidea (Dinophyceae) and Olisthodiscus luteus (Xanthophyceae) were grown in unialgal cultures in $\mathrm{f} / 2$ culture medium (based on Guillard's $F_{1}$ medium from Guillard \& Ryther 1962). Whole-cell extracts were made by centrifuging $13 \mathrm{~mm}^{3}$ of cells taken from cultures exhibiting exponential growth. They were put into $10 \mathrm{ml}$ of filtered seawater (henceforth meaning seawater that was filtered through a $0.8 \mu \mathrm{m}$ filter) and sonicated for three $30 \mathrm{~s}$ intervals, cooling the cells for intervals of 3 to $5 \mathrm{~min}$ after sonicating. The extract was then centrifuged at $5000 \mathrm{rpm}$ for $15 \mathrm{~min}$. The supernatant was poured off, filtered through a $0.8 \mu \mathrm{m}$ filter and brought up to a volume of $25 \mathrm{ml}$ with filtered seawater. Exudates from phytoplankton cultures were collected by vacuum filtering cells from the medium in which they were growing using a $0.8 \mu \mathrm{m}$ filter at pressure differentials of no more than $5 \mathrm{~mm} \mathrm{Hg}$.

Adult Centropages hamatus were collected from the Woods Hole Oceanographic Institution dock in Woods Hole, Massachusetts (USA) in July and August of 1983. Unless otherwise specified, the collected copepods were starved in filtered seawater for 6 to $8 \mathrm{~h}$ prior to the start of each experiment. The term 'acclimated copepods' refers to copepods fed Thalassiosira weissflogii for at least $24 \mathrm{~h}$ prior to the experiment.

Each experiment consisted of 3 replicate bottles. Each bottle contained $400 \mathrm{ml}$ of filtered seawater, 20 copepods, and an initial bead concentration of about 500 Sephadex G-50 Superfine (10 to $40 \mu \mathrm{m}$ ) beads $\mathrm{ml}^{-1}$. The beads had been rehydrated in filtered sea- 
water for $1 \mathrm{~h}$ prior to the start of the experiment. To each set of bottles a total of $2 \mathrm{ml}$ of phytoplankton extract or filtrate from a phytoplankton culture was added singly or in combinations of $1 \mathrm{ml}$ of each to determine the effects of these substances on copepod feeding behavior. Additions of $2 \mathrm{ml}$ of filtered seawater or $\mathrm{f} / 2$ culture medium were used as controls. Initial bead concentrations were determined by averaging Coulter counter measurements from 12 to 15 replicate samples from each bottle. Copepods were allowed to feed for $1 \mathrm{~h}$ while the bottles were rotated at 1 to 2 rev $\min ^{-1}$ to keep the beads suspended. Limiting the feeding experiments to $1 \mathrm{~h}$ ensured that there was insufficient time for the beads to pass through the guts of the copepods and then become resuspended in the seawater. Copepods were subsequently removed from the bottles and final bead concentrations were measured in 15 replicate bead samples from each bottle.

Differences in initial and final concentrations of beads were compared using a 2-way ANOVA without replication in which differences in initial bead concentrations were considered random effects and changes over time were examined. Single-classification ANOVA's were used to compare differences in ingestion rates. Multiple comparisons of mean ingestion rates were made using the T-method for unplanned comparisons (Sokal \& Rohlf 1981).

Results. There was no significant change over time in initial and final bead concentrations (based on the time component of a 2 -way ANOVA; $p<0.05$ ) when filtered seawater alone was added to the bottles (Fig. 1), indicating that Centropages hamatus would not ingest Sephadex beads in the absence of a chemical feeding stimulus. Likewise, addition of $\mathrm{f} / 2$ culture medium did not stimulate feeding. When Thalassiosira weissflogii and Scrippsiella trochoidea extracts or $T$. weissflogii medium were added there was a significant decrease in bead concentration $(p<0.025)$. Ingestion of beads flavored with $T$. weissflogii extract was significantly higher $(\mathrm{p}<0.05$; T-method) than with $S$. trochoidea-flavored beads. There was no difference ( $p>0.75$ ) between ingestion rates when $T$. weissflogii extract and $T$. weissflogii medium were added. Ingestion rates were also not significantly different in the presence of 1 rather than $2 \mathrm{ml}$ of $T$. weissflogil extract. And, there was no significant ( $p>0.05$ ) change in bead concentrations when either $S$. trochoidea medium or Olisthodiscus luteus extract were added. Copepods acclimated to live $T$. weissflogii for $1 \mathrm{~d}$ prior to the experiments did not significantly increase $(p>0.05)$ their consumption of beads flavored with $T$. weissflogii extract relative to copepods that had not been acclimated to $T$. weissflogii (Fig. 2). However, acclimated copepods did not ingest beads flavored with $S$. trochoidea extract.

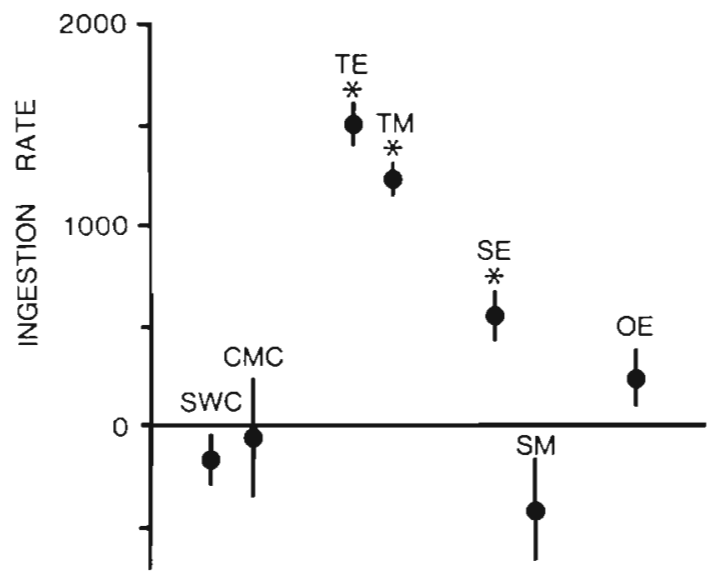

Fig. 1. Centropages hamatus. Mean ingestion rates of Sephadex beads (beads copepod ${ }^{-1} \mathrm{~h}^{-1}$ ) when phytoplankton extracts and exudates are added to the bead suspension. Vertical lines: $\pm 1 \mathrm{SE}$; asterisks: additives causing significant $(p<0.05)$ changes in bead concentration. SWC: seawater control; CMC: f/2 culture medium control; TE: Thalassiosira weissflogii extract; TM: $T$ weissflogii medium; SE: Scrippsiella trochoidea extract; SM: S. trochoidea medium; OE: Olisthodiscus luteus extract

In order to determine whether any of these phytoplankton extracts and exudates might have an inhibitory effect on feeding behavior, Scrippsiella trochoidea and Olisthodiscus luteus extracts and media were added in combination with Thalassiosira weissflogii extract. Addition of $S$. trochoidea extract with $T$. weissflogii extract resulted in significantly lower ingestion rates ( $p<0.05$ using the $T$-method) than when either substance was added separately (Table 1). Addition of $O$. luteus extract in combination with $T$. weissflogii extract resulted in ingestion rates intermediate be-

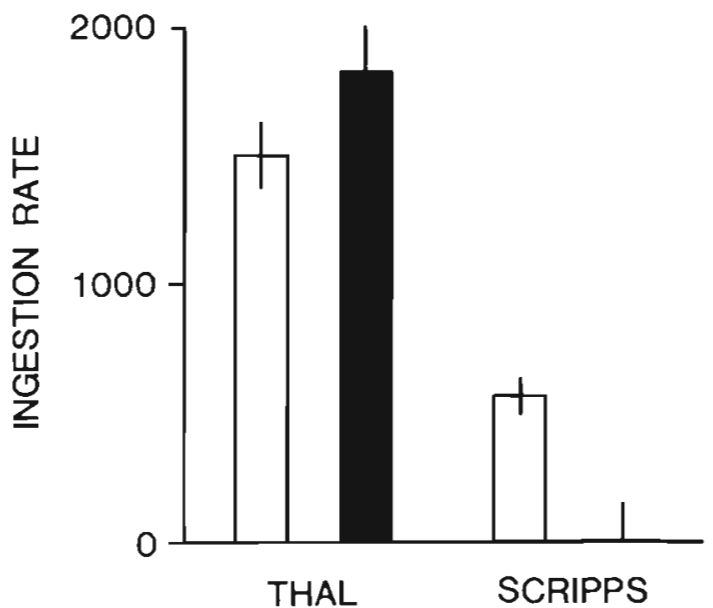

Fig. 2. Centropages hamatus. Mean ingestion rates (beads copepod ${ }^{-1} \mathrm{~h}^{-1}$ ) of Sephadex beads flavored by Thalassiosira weissflogii and Scrippsiella trochoidea. Solid bars: acclimated copepods; open bars: non-acclimated copepods; vertical lines: $\pm 1 \mathrm{SE}$ 
tween the ingestion rates obtained when either was added separately. Mean ingestion rates in the presence of $O$. luteus medium and $T$. weissflogii extract were $43 \%$ lower than those obtained when only $T$. weissflogil extract was added; however, due to high variance in ingestion rates these numbers were not significantly different.

Discussion. The responses by Centropages hamatus to the exudates and extracts of the 3 phytoplankton species correspond well with preferences shown by other copepod species. Digestive enzyme activity in Calanus pacificus drops when fed Scrippsiella trochoidea over a 24 d period (Hassett 1986). When fed Thalassiosira weissflogii, cellobiose activity drops but laminarase and maltase activity remain relatively constant. Hassett (1986) also showed that $C$. pacificus had a much lower survival rate when fed $S$. trochoidea than when fed $T$. weissflogii. And, Olisthodiscus luteus is known to be a less preferred food item for Acartia spp. (Tomas \& Deason 1981). Thus, $S$. trochoidea and $O$. luteus tend to be less preferred food items because of their chemical composition rather than because of their size or morphological features.

The negative responses of Centropages hamatus to Scrippsiella trochoidea and Olisthodiscus luteus are similar to the responses obtained by Huntley et al. (1986). They found that exudates but not homogenates of Protoceratium reticulatum inhibit feeding by Calanus pacificus on Gyrodinium resplendens. Many phytoplankters are known to produce toxins (Carmichael \& Gorham 1977, Schmidt \& Loeblich 1979, White 1980) or structures such as trichocysts (Ukeles \& Sweeney 1969) which could deter feeding by herbivorous zooplankton. Many other substances, which might serve as feeding cues, are released by marine algae. These include both simple and complex polysaccharides, sugar alcohols, amino acids, small peptides and larger proteins (Hellebust 1965, 1967). Chemoreceptor-like structures have been found the on heads and mouths of various copepod species (e.g. Elofsson 1971, Friedman \& Strickler 1975). However, it is not known at this time what kind of stimuli these receptors will respond to. Similar structures in decapod crustaceans serve as receptors for amino acids and simple sugars (Hartman \& Hartman 1977).

Responses to filtrates are probably more ecologically relevant than responses to extracts because copepods in nature are more likely to encounter exudates from whole cells rather than products coming from broken cells. These allelopathic substances that are released by phytoplankton are probably produced as feeding deterrents, however they might also be waste products of cell metabolism (Lewis 1986). Andrews (1983) has modelled the distribution of exudates being released from a single phytoplankton cell in the presence of a feeding current based on empirically derived values obtained from films of feeding copepods. High concentrations of phytoplankton exudates may be found within dense localized blooms of a particular phytoplankton species. For a single-celled organism such as a phytoplankter, being bad-smelling would be more advantageous than being bad-tasting. A predator would have to kill a cell in order to learn that it is badtasting, whereas it could recognize and avoid a badsmelling prey without harming it. However, producing a scent is energetically more expensive because the warning substances must be continuously produced and released. Being bad-tasting could be selectively advantageous if genetically identical clones would benefit from a predator's exposure to such cells. Such could be the case for asexually reproducing phytoplankters that are not rapidly dispersed. However, it is probably more likely that any bad-tasting compounds in these cells are simply being stored and then later released to dissuade potential predators.

Acknowledgements. I thank T. Cowles, J. Remillard, N. Copley, L. Cahoun, D. Egloff and D. Stoecker for providing advice and assistance throughout this study. K. Banse, T. Cowles, T. Daniel, P. Karieva, M. Mullin, R. Paine, R. Strathmann and 2 anonymous reviewers made many helpful comments.

Table 1. Centropages hamatus. Response to phytoplankton extracts and exudates. Initial and final concentrations of 10 to $40 \mu \mathrm{m}$ Sephadex beads (beads $\mathrm{ml}^{-1}$ ) and ingestion rates (beads copepod ${ }^{-1} \mathrm{~h}^{-1}$ ) are given as means \pm the standard error of the mean

\begin{tabular}{|lccc|}
\hline \multicolumn{1}{|c}{ Substances added } & Initial concentration & Final concentration & Ingestion rate \\
\hline Thalassiosira weissflogii extract (1 ml of extract) & $495 \pm 23$ & $438 \pm 21$ & $1150 \pm 77^{\circ}$ \\
Scrippsiella trochoidea extract \& T. weissflogii extract & $560 \pm 33$ & $557 \pm 9$ & $67 \pm 64$ \\
S. trochoidea extract & $634 \pm 18$ & $605 \pm 16$ & $567 \pm 82^{\circ}$ \\
Olisthodiscus luteus extract \& T. weissflogii extract & $511 \pm 21$ & $474 \pm 18$ & $740 \pm 110^{\circ}$ \\
O. luteus extract & $593 \pm 16$ & $585 \pm 19$ & $253 \pm 85$ \\
O. luteus medium \& $T$. weissflogii extract & $577 \pm 7$ & $541 \pm 23$ & $720 \pm 359$ \\
- Ingestion rates significantly (p <0.05) greater than zero using a t-test & & \\
\hline
\end{tabular}




\section{LITERATURE CITED}

Alcaraz, M., Paffenhöfer, G.-A., Strickler, J. R. (1980). Catching the algae: a first account of visual observations on filter-feeding calanoids. Am. Soc. Limnol. Oceanogr. Spec. Symp. 3: 241-248

Andrews, J. C. (1983). Deformation of the active space in the low Reynolds number feeding current of calanoid copepods. Can. J. Fish. aquat. Sci. 40: 1293-1302

Boyd, C. M. (1976). Selection of particle sizes by filter-feeding copepods: a plea for reason. Limnol. Oceanogr. 21: 175-180

Carmichael, W. W., Gorham, P. R. (1977). Factors influencing the toxicity and animal susceptibility of Anabaena flosaquae (Cyanophyta) blooms. J. Phycol. 13: 97-101

Donaghay, P. L., Small, L. F. (1979). Food selection capabilities of the estuarine copepod Acartia tonsa. Mar. Biol. 52: 137-146

Elofsson, R. (1971). The ultrastructure of a chemoreceptor organ in the head of copepod crustaceans. Acta zool, Stockh. 52: 299-315

Friedman, M. M., Strickler, J. R. (1975). Chemoreception and feeding in the calanoid copepods. Proc. natn. Acad. Sci. USA 72: 4185-4188

Frost, B. (1977). Feeding behavior of Calanus pacificus in mixtures of food particles. Limnol. Oceanogr. 22: 472-491

Guillard, R. R. L., Ryther, J. H. (1962). Studies on marine planktonic diatoms. I. Cyclotella nana Hustedt and Detonula confervacea (Cleve) Gran. Can. J. Microbiol. 8: 229-239

Hartman, H. B., Hartman, M. S. (1977). Stimulation of filterfeeding in the porcelain crab Petrolisthes cinetipes Randall by amino acid and sugar. Comp. Biochem. Physiol. 56 A: $19-22$

Hassett, R. P. (1986). The effect of feeding history on the feeding behavior of Calanus pacificus. Ph.D. thesis. Univ. of Washington, Seattle

Hellebust, J. A. (1965). Excretion of some organic compounds by marine phytoplankton. Limnol. Oceanogr. 10: 192-206
Hellebust, J. A. (1967). Extracellular products. In: Stewart, W. D. (ed.) Algal physiology and biochemistry. Univ. Calif. Press, Berkeley, p. 838-863

Huntley, M., Sykes, P., Rohan, S., Marin, V. (1986). Chemically mediated rejection of dinoflagellate prey by the copepods Calanus pacificus and Paracalanus parvus: mechanism, occurrence, and significance. Mar. Ecol. Prog. Ser. 28: 105-120

Huntley, M. E., Barthel, K.-G., Star, T. L. (1983). Particle rejection by Calanus pacificus: discrimination between similarly sized particles. Mar. Biol. 74: 151-160

Koehl, M. A. R., Strickler, J. R. (1981). Copepod feeding currents: food capture at low Reynolds numbers. Limnol. Oceanogr. 26: 1062-1073

Lewis, W. M. (1986). Evolutionary interpretations of allelochemical interactions in phytoplankton algae. Am. Nat. 127: $184-194$

Nival, P., Nival, S. (1976). Particle retention efficiencies of an herbivorous copepod, Acartia clausi (adult and copepodite stages): effects on grazing. Limnol. Oceanogr. 21: 24-38

Schmidt, R. J., Loeblich, A. R. (1979). Distribution of paralytic shellfish poisoning among Pyrrhophyta. J. mar. biol. Ass. U.K. 59: 479-487

Sokal, R. R., Rohlf, F. J. (1981). Biometry. W. H. Freeman and Co., New York

Tomas, C. R., Deason, E. E. (1981). The influence of grazing by two Acartia species on Olisthodiscus luteus Carter. P.S.Z.N.I. Mar. Ecol. 2: 215-223

Ukeles, R., Sweeney, B. M. (1969). Influence of dinoflagellate trichocyts and other factors on the feeding of Crassostrea virginica larvae on Monochrysis lutheri. Limnol. Oceanogr. 14: 403-410

White, A. (1980). Recurrence kills of Atlantic herring (Clupea harengus harengus) caused by dinoflagellate toxins transferred through herbivorous copepods. Can. J. Fish. aquat. Sci. 37: 2262-2265

Accepted for printing on August 24, 1986 